\title{
Follicular dendritic cell sarcoma of the palatine tonsil
}

\author{
Palatin tonsilin foliküler dentritik hücreli sarkomu
}

\author{
Fatih Çelenk, ${ }^{1}$ Suna Erkılıç, ${ }^{2}$ Elif Baysal, ${ }^{1}$ Cengiz Durucu, ${ }^{1}$ Muzaffer Kanlıkama ${ }^{1}$ \\ ${ }^{1}$ Department of Otolaryngology, Medical Faculty of Gaziantep University, Gaziantep, Turkey \\ ${ }^{2}$ Department of Pathology, Medical Faculty of Gaziantep University, Gaziantep, Turkey
}

\begin{abstract}
Tumors arising from follicular dendritic cells are relatively uncommon. Although most of them originate from the lymph nodes, extranodal sites can also be involved. In this article, we report a 62-year-old male case with a very rare tonsillar follicular dendritic cell sarcoma. The diagnosis was based on histopathologic examination and immunohistochemical staining. He was treated successfully with surgical excision, neck dissection and postoperative radiotherapy. No recurrence was observed during a 18 month follow-up.

Key Words: Follicular dentritic cell sarcoma; neck dissection; radiation therapy; tonsil.
\end{abstract}

Follicular dendritic cells are non-lymphoid and nonphagocytic accessory cells of the immune system and are generally found in the germinal centers of primary and secondary lymphoid follicules. ${ }^{[1,2]}$ They serve as antigenpresenting cells, play a major role in the induction and maintenance of the humoral immune response and stimulate B-cell proliferation and differentiation. ${ }^{[3,4]}$ Follicular dendritic cells have complement receptors and human leukocyte antigen-DR on their surface and can be identified immunohistochemically. ${ }^{[1]}$

Follicular dendritic cell sarcoma (FDCS) is a rare malignant tumor originating from follicular dendritic cells. Although most of these tumors occur in lymph nodes, various extranodal sites can also be affected. The tonsil is an uncommon site of occurrence for FDCS. Wide local excision with or without neck dissection is the primary treatment of these tumors. Adjuvant treatment such as radiotherapy and chemotherapy are
Foliküler dendritik hücrelerden gelişen tümörler oldukça nadirdir. Bunların çoğu lenf nodlarından gelişse de çeşitli ekstranodal bölgeler de tutulabilir. Bu yazıda oldukça nadir görülen tonsilin folliküler dendritik hücreli sarkomu olan 62 yaşındaki erkek bir olgu sunuldu. Tanı histopatolojik inceleme ve immünohistokimyasal boyama ile konuldu. Hasta cerrahi eksizyon, boyun diseksiyonu ve ameliyat sonrası radyoterapi ile başarılı bir şekilde tedavi edildi. On sekiz aylık takipte nüks gözlenmedi.

Anahtar Sözcükler: Foliküler dendritik hücreli sarkom; boyun diseksiyonu; radyasyon tedavisi; tonsil.

also recommended. We report a rare case of FDCS originating from the right tonsil.

\section{CASE REPORT}

A 62-year-old man presented with a three-month history of difficulty on swallowing, a gradually enlarging painless mass around his right tonsil and globus sensation when swallowing. He did not report any symptoms associated with recent upper respiratory infection. There were no co-occurring diseases or history of tobacco intake. A thorough head and neck examination was performed and a $25 \times 15 \mathrm{~mm}$ indurated mass located between the anterior and posterior tonsillar pillars was detected (Figure 1). The mass was lobulated and completely occupying the right tonsillar fossa. Neck examination did not reveal any enlarged lymph nodes. Magnetic resonance imaging (MRI) and computed tomography (CT) scans demonstrated a $22 \times 12 \mathrm{~mm}$ 


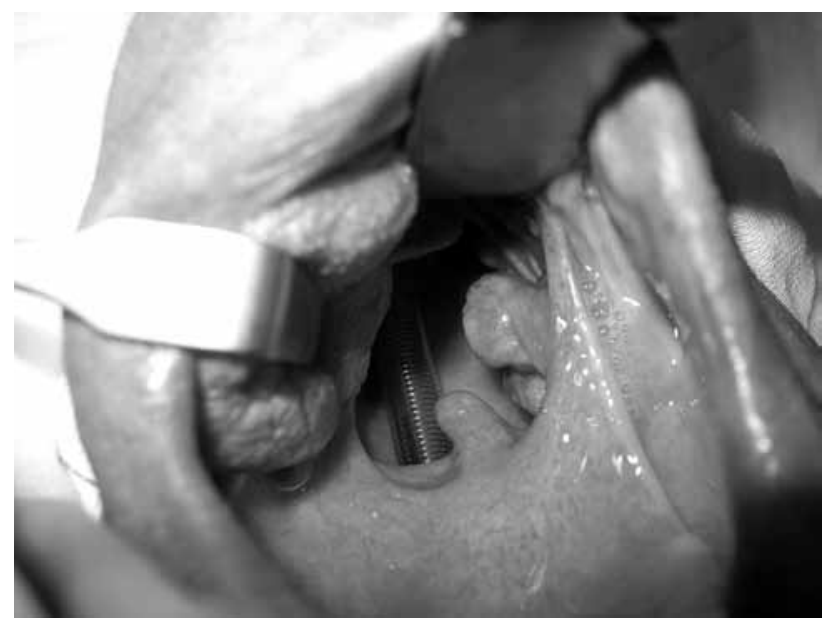

Figure 1. An indurated mass located between the anterior tonsillar pillar and tonsil and occupying two thirds of the anterior surface of the tonsil.

lobulated, well-defined soft tissue mass involving the right tonsillar fossa and slightly extending to the parapharyngeal space (Figure 1 and 2). Although the gross appearance of the mass was consistent with a neoplastic disease, a punch biopsy was performed before definitive surgical treatment due to the atypical appearance of the lesion. Histopathologic examination was consistent with FDCS.

The tumor and the right tonsil were excised completely with wide surgical margins. We also performed a right supraomohyoid neck dissection. The diagnosis of FDCS was confirmed by postoperative histopathologic examination. The surgical margins were tumor-free. The tumor was made up of spindleshaped cells with hyperchromatic nuclei and high mitotic activity under the stratified squamous epithelium (Figure 3). Immunohistochemical staining showed that the tumor cells were positive for CD21 (Figure 4), CD23, CD35, CD68, vimentin and S-100. Histopathologic examination of the neck dissection specimen did not reveal any lymph node metastasis. The patient received radiotherapy following surgical treatment. Postoperative positron emission tomography did not show any evidence of residual or recurrent disease at both primary site and the neck. Follow-up of 18 months showed no recurrence.

\section{DISCUSSION}

Follicular dendritic cell sarcoma is a rarely seen neoplasm arising from follicular dendritic cells of the immune system. This tumor is generally seen in young and middle-aged adults. ${ }^{[5]}$ Most of these tumors occur in lymph nodes; however, several extranodal sites including the liver, tonsil and intraabdominal soft tissue can also be affected. ${ }^{[6,7]}$

As the gross appearance of the tumor is not specific, the diagnosis of FDCS of the tonsil is typically based on histopathologic examination. Histopathological findings of follicular dendritic cell tumors include spindleshaped arrangement of cells, high mitotic activity and focal storiform or whorled growth pattern of cells..$^{[2,5,8,9]}$ Follicular dendritic cell sarcoma is generally positive for CD21, CD35, KiM4p, KiFDC1p, vimentin, S-100 protein, CD68 and specific muscle actin. ${ }^{[2]} \mathrm{CD} 21$ and CD35 are the most useful antibodies because of their sensitivity and specificity. ${ }^{[3]} \mathrm{CD} 21$ is expressed strongly in approximately $96 \%$ of cases, but occasionally the staining can be patchy or weak. ${ }^{[10]}$ In our case
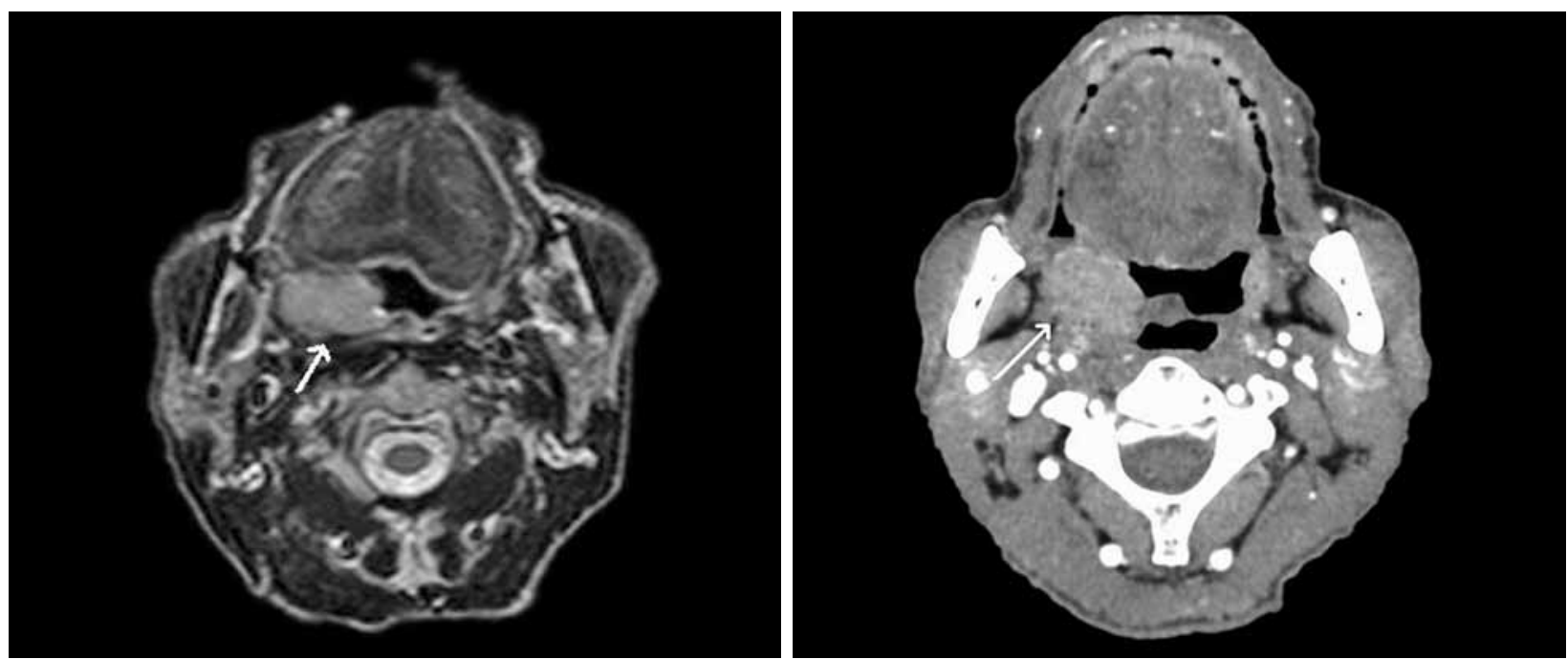

Figure 2. A lobulated and well-defined soft tissue mass involving the right tonsillar fossa and slightly extending to the parapharyngeal space (white arrows). 


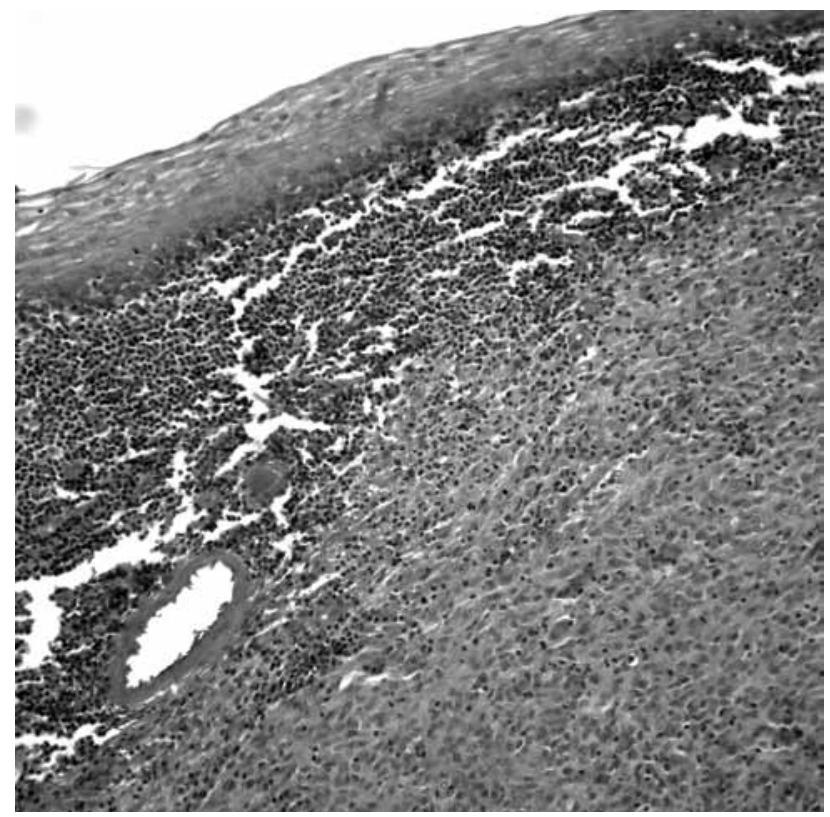

Figure 3. The tumor was made up of spindle-shaped cells with hyperchromatic nuclei and high mitotic activity under the stratified squamous epithelium (H-E x 200).

spindle-shaped cells with hyperchromatic nuclei and high mitotic activity under the stratified squamous epithelium were found in histopathologic examination. Immunohistochemical staining showed that the tumor cells were positive for CD21, CD23, CD35, CD68, vimentin and $\mathrm{S}-100$.

The differential diagnosis of FDCS includes ectopic meningioma, interstitial reticulum cell sarcoma, lymphoepithelial carcinoma, undifferentiated carcinoma, malignant melanoma, thymoma, malignant fibrous histiocytoma and large cell lymphoma. ${ }^{[1,5,6,8]}$ None of these tumors express CD21, CD35, KiM4p or KiFDC1p in immunohistochemical studies and their structural profiles are substantially different from FDCS. ${ }^{[8,11]}$ The microscopic features such as storiform pattern, syncytial and spindle cells, bland nuclei with small but distinct nucleoli are additional diagnostic clues. ${ }^{[10]}$

Follicular dendritic cell sarcoma is considered as a low-and intermediate-grade malignant neoplasm. ${ }^{[11,12]}$ According to Chan et al. ${ }^{[7]}$ several factors may be associated with poor prognosis including tumor size $(\geq 6 \mathrm{~cm})$, intraabdominal location, presence of coagulative necrosis, high mitotic count, significant cellular atypia and lack of adjuvant therapy.

The primary treatment for FDCS is wide surgical excision. According to some authors regional lymph node dissection should be performed only in case of radiologically detected

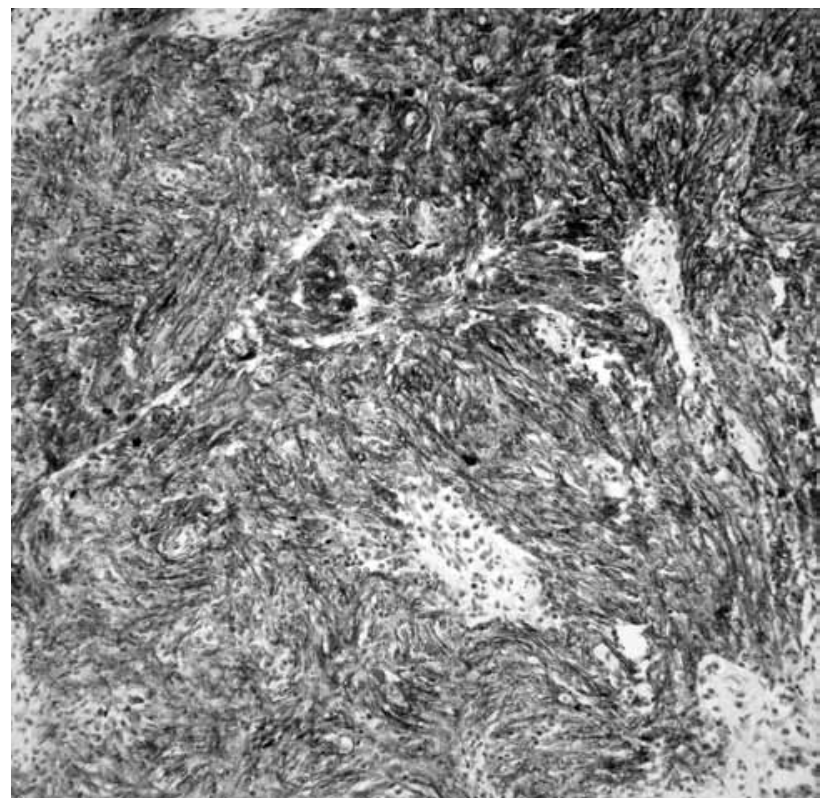

Figure 4. Immunohistochemical staining was positive for CD21 (CD21 x 200).

metastasis. ${ }^{[8]}$ Perez-Ordonez et al. ${ }^{[5]}$ suggested that adjuvant radiotherapy may provide some benefit for residual or locally recurrent tumors. Some authors suggest that adjuvant radiotherapy or chemotherapy is indicated in cases with adverse pathologic features, and in advanced or incompletely resected tumors. ${ }^{[3,9]}$ In the current case, following definitive surgical treatment, adjuvant radiotherapy was performed due to high mitotic activity of the tumor cells.

In conclusion, FDCS should be included in the differential diagnosis of any tonsillar mass. If the diagnosis of FDCS is suspected, immunohistochemical staining should be done. Once the diagnosis is confirmed, wide surgical excision and if required, adjuvant therapies should be performed.

\section{Declaration of conflicting interests}

The authors declared no conflicts of interest with respect to the authorship and/or publication of this article.

\section{Funding}

The authors received no financial support for the research and/or authorship of this article.

\section{REFERENCES}

1. Aydin E, Ozluoglu LN, Demirhan B, Arikan U. Follicular dendritic cell sarcoma of the tonsil: case report. Eur Arch Otorhinolaryngol 2006;263:1155-7.

2. Clement P, Saint-Blancard P, Minvielle F, Le Page P, Kossowski M. Follicular dendritic cell sarcoma of the tonsil: a case report. Am J Otolaryngol 2006;27:207-10. 
3. Eun YG, Kim SW, Kwon KH. Follicular dendritic cell sarcoma of the tonsil. Yonsei Med J 2010;51:602-4.

4. Fonseca R, Yamakawa M, Nakamura S, van Heerde P, Miettinen M, Shek TW, et al. Follicular dendritic cell sarcoma and interdigitating reticulum cell sarcoma: a review. Am J Hematol 1998;59:161-7.

5. Perez-Ordonez B, Erlandson RA, Rosai J. Follicular dendritic cell tumor: report of 13 additional cases of a distinctive entity. Am J Surg Pathol 1996;20:944-55.

6. Satoh K, Hibi G, Yamamoto Y, Urano M, Kuroda M, Nakamura S. Follicular dendritic cell tumor in the oropharyngeal region: report of a case and a review of the literature. Oral Oncol 2003;39:415-9.

7. Chan JK, Fletcher CD, Nayler SJ, Cooper K. Follicular dendritic cell sarcoma. Clinicopathologic analysis of 17 cases suggesting a malignant potential higher than currently recognized. Cancer 1997;79:294-313.
8. Tisch M, Hengstermann F, Kraft K, von Hinüber G, Maier H. Follicular dendritic cell sarcoma of the tonsil: report of a rare case. Ear Nose Throat J 2003;82:507-9.

9. Khalid T, Folman R. Symptoms in cancer patients and an unusual tumor: Case 3. Follicular dendritic cell sarcoma. J Clin Oncol 2005;23:9425-6.

10. Bothra R, Pai PS, Chaturvedi P, Majeed TA, Singh C, Gujral S, et al. Follicular dendritic cell tumour of tonsil - is it an under-diagnosed entity? Indian J Cancer 2005;42:211-4.

11. McDuffie C, Lian TS, Thibodeaux J. Follicular dendritic cell sarcoma of the tonsil: a case report and literature review. Ear Nose Throat J 2007;86:234-5.

12. Vaideeswar P, George SM, Kane SV, Chaturvedi RA, Pandit SP. Extranodal follicular dendritic cell sarcoma of the tonsil - case report of an epithelioid cell variant with osteoclastic giant cells. Pathol Res Pract 2009;205:149-53. 